\title{
Meningkatkan Hasil dan Motivasi belajar Bahasa Arab Melalui Model Pembelajaran Kooperatif Tipe Teams Games Tournament Pada Materi Identitas Diri di Kelas X Agama 1 MAN-1 Pekanbaru Tahun Pelajaran 2018-2019
}

\author{
Marzuki \\ Guru/Kepala Madrasah MAN-1 Pekanbaru
}

\section{INFO ARTIKEL}

\section{Riwayat Artikel:}

Diterima: 15-12-2019

Disetujui: 22-12-2019

\section{Kata kunci:}

Hasil Belajar

Motivasi Belajar

Teams Games Tournament

Pembelajaran Kooperatif

\author{
Alamat Korespondensi: \\ Marzuki \\ Guru/Kepala MAN 1 Pekanbaru \\ Jl. Bandeng, Pekanbaru \\ E-mail: marzuki@gmail.com
}

\begin{abstract}
ABSTRAK
Abstract: The purpose of this study was to describe the effect of the application of Cooperative Learning Type Teams Games Tournament as seen from the motivation and student learning outcomes in Arabic subjects. The material introduces itself in the Xsc class of Religion 1 MAN-1 Pekanbaru. This type of research is Classroom Action Research (CAR), where teachers take teacher reflective actions to improve the learning process. This research consisted of 2 cycles. The first cycle is carried out in 4 meetings and the second cycle is carried out with 4 meetings. Each cycle consists of planning, implementing, observing and reflecting. The assessment instrument used was a questionnaire motivational learning list and a matter of knowledge for daily assessment. The results showed that Cooperative Learning Type Teams Games Tournament (TGT) can increase student motivation and learning outcomes. Student learning motivation in cycle 1 in the excellent, good and quite categories respectively $28.12 \%, 56.25 \%$ and $15.62 \%$ while in cycle 2 respectively amounted to $34.37 \%, 59.37 \%$ and $6.25 \%$. While student learning outcomes increased from $68.75 \%$ in cycle 1 to 87.5 in cycle 2 . The conclusion of this study is that Cooperative Learning Teams Games Tournament (TGT) can increase motivation and learning outcomes for Arabic language introducing themselves (KD 3.2) in the Xsc class of Religion 1 MAN-1 Pekanbaru in the 2018-2019 school year.
\end{abstract}

Abstrak: Tujuan Penelitian ini adalah untuk mendeskripsikan pengaruh penerapan pembelajaran Kooperatif Tipe Teams Games Tournament yang dilihat dari motivasi dan hasil belajar siswa pada mata pelajaran bahasa arab Materi memperkenalkan diri di kelas Xsc Agama 1 MAN-1 Pekanbaru. Jenis Penelitian ini adalah Penelitian Tindakan Kelas (PTK), dimana guru melakukan tindakan reflektif guru untuk memperbaiki proses pembelajaran. Penelitian ini terdiri dari 2 siklus. Siklus pertama dilakukan dalam 4 kali pertemuan dan siklus ke 2 dilaksanakan dengan 4 kali pertemuan. Setiap siklus terdiri dari perencanaan, pelaksanaan, observasi dan refleksi. Instrumen penilaian yang digunakan adalah angket motivasi belajar daftar dan soal pengetahuan untuk Penilaian harian. Hasil Penelitian menunjukkan bahwa Pembelajaran Kooperatif Tipe Teams Games Tournament (TGT) dapat meningkatkan motivasi dan hasil belajar siswa. Motivasi belajar siswa pada siklus 1 pada kategori sangat baik, baik dan cukup berturut-turut masing-masing 28,12\%, 56,25\% dan 15,62\% sementara pada siklus 2 berturut-turut sebesar 34,37\%, 59,37\% dan 6,25\%. Sementara Hasil belajar siswa meningkat dari $68,75 \%$ pada siklus 1 menjadi 87,5 pada siklus 2. Kesimpulan dari penelitian ini adalah Pembelajaran Kooperatif Tipe Teams Games Tournament (TGT) dapat meningkatkan motivasi dan hasil belajar Bahasa Arab materi memperkenalkan diri (KD 3.2) pada kelas Xsc Agama 1 MAN-1 Pekanbaru Tahun ajaran 2018-2019. 


\section{LATAR BELAKANG}

Saat ini sistem pendidikan yang tertuang dalam kurikulum telah mengalami kemajuan yang pesat. Berbagai strategi dan model pembelajaran diterapkan dalam proses belajar mengajar, dengan harapan pengajaran guru akan lebih berkesan dan bermakna bagi siswa. Proses kegiatan belajar mengajar di dalam kelas harus diterapkan dengan menggunakan berbagai model pembelajaran, dengan harapan siswa sebagai subjek didik dapat menerima bahan pelajaran dengan baik dan memberikan hasil yang memuaskan. Setiap proses pembelajaran yang berlangsung harus memperhatikan potensi individual siswa serta kinerja otak dan emosi. Metode pengajaran tersebut harus dapat mengaktifkan tidak hanya otak kiri tetapi juga otak kanan. Karena diketahui bahwa otak kanan memiliki kemampuan berpikir imajinatif, holistic dan kreatif serta bisa menghasilkan ide-ide di luar pakem yang biasa diamati otak kiri (Asbullah, 2008). Penggunaan otak kiri dan kanan secara bersama diharapkan dapat menghasilkan keseimbangan yang akhirnya meningkatkan penguasaan materi pelajaran.

Namun saat ini capaian kognitif peserta didik pada beberapa mata pelajaran masih belum memuaskan, salah satunya pada mata pelajaran bahasa Arab. Mata pelajaran bahasa arab merupakan pelajaran wajib yang termasuk kedalam struktruk kurikulum suatu madrasah. Pada madrasah aliyah (setingkat SMA) bahasa arab diajarkan sebanyak 3 jam pelajaran per minggu untuk jurusan ilmu alam (MIA) dan jurusan sosial (IIS). Sementara untuk siswa jurusan agama jumlah pertemuan mata pelajaran bahasa arab diajarkan 4-5 jam per minggu. Untuk meningkatkan pemahaman siswa terhadap materi pelajaran, khususnya mata pelajaran Bahasa Arab, maka perlu diterapkan model pengajaran yang lebih menarik. Penerapan model pengajaran, diharapkan dapat meningkatkan penguasaan dan pemahaman siswa terhadap materi yang diajarkan. Ketersediaan waktu pembelajaran juga merupakan salah satu faktor yang dapat menjadi pertimbangan metode apa yang akan digunakan seorang guru dalam menyampaikan materinya.

Berdasarkan masalah yang dikemukakan di atas, perlu dilakukan tindakan di kelas X, khususnya kelas X jurusan agama, karena siswa siswa jurusan agama diharapkan dapat melanjutkan pendidikan ke timur tengah dimana kemampuan berbahasa arab menjadi salaha satu syarat utamanya. Dari hasil tindakan yang diberikan diharapkan hasil belajar dan motivasi siswa meningkat. Motivasi yang diharapkan meningkat disini adalah kesediaan dan keinginan yang kuat dari peserta didik untuk belajar secara aktif, kreatif, efektif, inovatif, dan menyenangkan dalam rangka perubahan perilaku, baik dalam aspek kognitif, afektif, dan psikomotor. Hal ini penting karena motivasi merupakan salah satu faktor yang berpengaruh di dalam proses pembelajaran. Sementara hasil belajar yang diharapkan adalah tercapainya kompetensi kognitif, afektif dan keterampilan yang sesuai dengan kriteria ketuntasan. Peneliti (guru) akan menempatkan siswa sebagai subjek belajar, dan mengembangkan potensi dan kemampuan sosialnya secara optimal, karena siswa akan lebih mudah membangun dan mengembangkan pemahaman melalui interaksi sosial.

Salah satu model pembelajaran kooperatif yang dapat diterapkan untuk peningkatan pemahaman siswa dalam pelajaran Bahasa arab adalah model Teams Games Tournament (TGT). Model belajar ini lebih banyak melibatkan siswa secara aktif dalam mendiskusikan materi pelajaran dan membahas soal-soal dengan kompetisi antar kelompok. Dinamika kompetisi akan meningkatkan daya saing sehingga siswa akan berperan lebih aktif, apalagi jika soal-soal dibahas dengan menggunakan suatu permainan. Suasana kompetisi juga akan menghidupkan kelas dan membangun semangat.Dengan demikian materimateri yang susah dipelajari diharapkan lebih mudah dipahami. Model pembelajaran kooperatif tipe Team Games Tournament (TGT) dipilih karena pembelajaran ini melibatkan aktivitas seluruh siswa tanpa harus ada perbedaan status, melibatkan peran siswa sebagai tutor sebaya, mengandung unsur permainan dan penguatan yang memungkinkan siswa dapat belajar lebih rileks selain menumbuhkan tanggung jawab, kejujuran, kerja sama, persaingan sehat serta keterlibatan belajar. Selain itu juga pembelajaran kooperatif tipe TGT dapat menambahkan dimensi kegembiraan yang diperoleh dari permainan. Teman satu tim akan saling membantu dalam mempersiapkan diri untuk permainan dengan mempelajari lembar kegiatan dan menjelaskan masalah-masalah satu sama lain, tetapi sewaktu siswa sedang bermain dalam game temannya tidak boleh membantu, memastikan telah terjadi tanggung jawab individual (Slavin, 2009).

Untuk meningkatkan capaian hasil dan motivasi belajar salah satu model yang dapat digunakan adalah teams games Tournament. TGT menggunakan Turnamen Akademik, dan menggunakan kuis-kuis dan sistem skor kemajuan individu, di mana para siswa berlomba-lomba sebagai wakil tim meraka dengan anggota tim lain yang kinerja akademik sebelumnya setara seperti mereka.. (Robert E. Slavin, 2010). Dalam TGT peserta didik memainkan permainan-permainan dengan anggota tim lain untuk memperoleh skor bagi tim mereka masing-masing. Penyusunan permainan dapat disusun dalam bentuk kuis berupa pertanyaan yang berkaitan dengan materi pelajaran. Model Pembelajaran Kooperatif tipe Teams-GamesTournament (TGT), atau pertandingan permainan tim dikembangkang secara asli oleh David De Vries dan Keath Edward (1995). Pada Model ini siswa memainkan permainan dengan anggota-anggota tim lain untuk memperoleh tambahan poin untuk skor tim mereka. (Trianto, 2010) Langkah-langkah TGT disajikan dalam beberapa tahapan yaitu: 1). Presentasi Kelas (Penyajian Kelas) yaitu: Materi dalam TGT pertama- tama diperkenalkan dalam presentasi di dalam kelas. Ini merupakan pengajaran langsung seperti yang sering kali dilakukan atau diskusi pelajaran yang dipimpin oleh guru, tetapi bisa juga memasukkan presentasi Audiovisual. 2) Kelompok (tim) Tim terdiri dari empat atau lima siswa yang mewakili seluruh bagian dari kelas dalam hal kinerja akademik, jenis kelamin, ras dan etnistas. Fungsi utama dari tim ini adalah memastikan bahwa semua anggota tim benar-benar belajar 3) Game, Gamenya terdiri atas pertanyaan-pertanyaan yang kontennya relevan yang dirancang untuk menguji pengetahuan siswa yang diperolehnya dari presentasi di kelas dan pelaksanaan kerjaa tim. 4) Turnamen, Turnamen adalah sebuah struktur di mana game berlangsung. 


\section{METODE}

Penelitian ini dilakukan dengan Penelitian Tindakan Kelas (PTK) atau Classroom Action Research merupakan suatu model penelitian yang diterapkan di kelas dengan Model Teams Games Tournament. Penelitian ini dilaksanakan di MAN 1 Pekanbaru di kelas Xsc agama 1 dengan jumlah siswa 32 orang. Pelaksanaan tindakan terdiri dari 2 siklus dengan total jumlah pertemuan 8 kali. Dilaksanakan semester ganjil tahun ajaran 2018-2019. Menurut Arikunto (2006) secara garis besar penelitian tindakan kelas terdapat empat tahapan, yaitu :1) perencanaan. 2) pelaksanaan. 3) pengamatan. 4) refleksi. Di dalam pelaksanaan penelitian ini akan menggunakan beberapa siklus, setiap berakhir pada satu siklus akan direpleksikan pada siklus berikutnya:

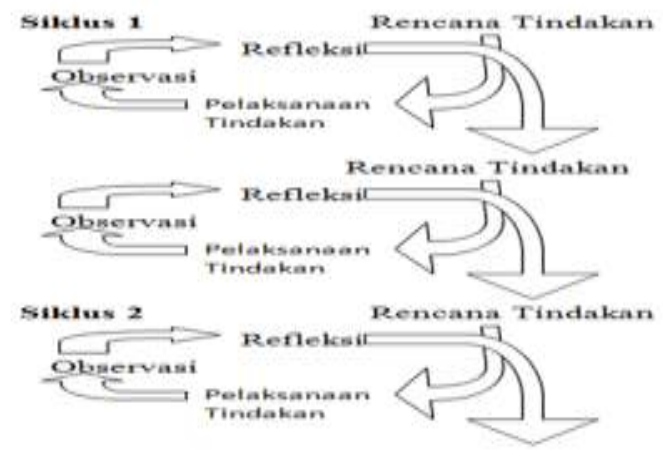

\section{Gambar 1. Hubungan Komponen Pokok Penelitian Tindakan kelas}

Prosedur penelitian melalui tahapan pembelajaran yakni perencanaan, tindakan, observasi dan refleksi. Pada tahap perencanaan, kegiatan yang dilakukan antara lain: 1) Kegiatan pendahuluan, kegiatan inti, kegiatan penutup yang disesuaikan dengan metode pemberian lembaran tugas dan menjawab pertanyaan; 2) Memilih pokok bahasan untuk penerapan pembelajaran dengan pemberian lembaran tugas, dengan kompetensi dasar penelitian ini adalah dengan membuat silabus, RPP dan LKS; 3) Menentukan kelompok belajar dengan jumlah masing-masing 4-5 orang siswa; 4) Merencanakan angket motivasi dengan untuk mengukur motivasi siswa; 5) Menyiapkan alat evaluasi berupa penilaian hasil kerja kelompok (LKS ) dan individu dan membuat soal-soal ulangan harian, dengan KKM 75 dengan target pencapaian 75 $\%$ tuntas dan yang tidak tuntas diadakan remedial. Yang tidak tuntas menjadi acuan untuk melakukan penelitian siklus ke II; dan 6) Merencanakan refleksi setiap akhir siklus dilaksanakan. Pada tahap tindakan, kegiatan yang dilaksanakan adalah melaksanakan RPP yang direncanakan. Pelaksana tindakan adalah peneliti sebagai guru Bahasa arab. Pelaksanaan penelitian bersamaan dengan observasi, terdiri dari beberapa siklus dengan: 1) Menetapkan pelaksanaan jumlah siklus bergantung hasil siklus I; 2) Melaksanakan pembelajaran kooperatif Model Teams games Tournament. Model adalah representasi realitas yang disajikan dengan suatu derajat struktur dan urutan. TGT adalah penerapan model belajar dengan cara mengelompokkan siswa secara heterogen, setelah memperoleh tugas setiap kelompok bekerja sama dalam bentuk kerja individual dan diskusi. Suasana diskusi dibuat senyaman mungkin seperti dalam kondisi suatu permainan. Tahap terakhir adalah evaluasi, melaksanakan evaluasi berupa format penilian hasil kerja kelompok dan individu dan membuat soal-soal ulangan harian, dengan KKM 75 dengan target pencapai $75 \%$ tuntas dan yang tidak tuntas diadakan remedial. Yang tidak tuntas menjadi acuan untuk melakukan refleksi pada penelitian siklus ke II.

Dalam penelitian ini instrument yang digunakan berupa tes objektif dalam bentuk pilihan ganda. Data yang dikumpulkan adalah data kuantitatif. Menurut BNSP Departemen Pendidikan Nasional (2006) pengolahan hasil belajar untuk pemahaman konsep dengan soal objektif. Untuk data motivsi belajar didasarkan pada Indikator yaitu : 1) adanya motivasi dan hasrat serta keinginan untuk berhasil, 2) adanya dorongan dan kebutuhan untuk belajar, 3) adanya harapan dan cita-cita masa depan, 4) adanya penghargaan dalam belajar dan 5) adanya kegiatan yang menraik saat pembelajaran. Dari hasil angket motivasi yang nantinya didapat akan dianalisis per indikator didasarkan pada kriteria yang disajikan pada Tabel 1 berikut.

Tabel 1. Interval dan Kategori Angket Motivasi Belajar

\begin{tabular}{cccc}
\hline No & Interval nilai & Katgeori & Nilai \\
\hline 1 & $85,00-100$ & Sangat baik & A \\
2 & $75,00-84,00$ & Baik & B \\
3 & $65,00-74,00$ & Cukup & C \\
4 & $<65,00$ & Kurang & D \\
\hline (Sumber : Imam Surrono, 2011) &
\end{tabular}

(Sumber : Imam Suryono, 2011) 


\section{HASIL}

Penelitian ini merupakan penelitian tindakan kelas yang dilakukan dalam 2 siklus yang sebelumnya diadakan pembentukan kelompok oleh guru. Pembagian kelompok dilakukan secara heterogen dimana setiap kelompok memiliki kemampuan yang beragam (Terlampir). Tindakan yang dilakukan berupa penerapan pembelajaran kooperatif tipe TGT. Siklus 1 dilakukan dalam 4 kali pertemuan dengan materi pelajaran Mufradat tentang Identitas diri, dan Hiwar tentang Identitas diri, Sedangkan siklus ke dua dilakukan juga dalam 4 kali pertemuan dengan materi pelajaran tentang qiraah yang berkaitan dengan البيانات Tarkib tentang Isim Nakirah dan Isim Ma'rifah. Data yang dikumpulkan berupa hasil belajar siswa baik dalam mengerjakan LKS maupun dalam menjawab soal-soal pada tournament serta ketuntasan pada pelaksanaan ulangan harian. Untuk motivasi siswa maka dilakukan observasi oleh observer dan penyebaran angket motivasi yang terdiri dari 5 indikator.

Setelah berlatih pada kelompok masing-masing, maka turnament dimulai dengan cara memanggil setiap perwakilan anggota kelompok sesuai tipe soal yang sudah sepakati. Hasil skor turnament siklus 1 RPP 1 (pertemuan 2) disajikan pada Tabel 2 berikut.

Tabel 4.1. Hasil Skor Turnament Siklus 1, RPP 1

\begin{tabular}{llcccc}
\hline \multirow{2}{*}{ No } & Materi Mufradat tentang Identitas diri & \multicolumn{4}{c}{ Jawaban siswa } \\
\cline { 3 - 6 } & & Benar & $(\%)$ & $\begin{array}{c}\mathrm{F} \\
\text { Salah }\end{array}$ & $(\%)$ \\
\hline 1 & Soal A & - & 0 & 5 & 100 \\
2 & Soal B & 1 & 20 & 4 & 80 \\
3 & Soal C & 2 & 40 & 3 & 60 \\
4 & Soal D & 2 & 40 & 3 & 60 \\
5 & Soal E & 5 & 100 & 0 & 0 \\
\hline
\end{tabular}

Dari Tabel 2 diatas terlihat bahwa untuk soal tipe A atau sangat sulit belum ada peserta didik yang dapat menjawab, sementara untuk tipe soal E, soal mudah dijawab dengan benar oleh setiap perwakilan kelompok. Selanjutnya Hasil skor turnament 2 siklus 1 (RPP Pertemuan 4) disajikan pada Tabel 3 berikut.

Tabel 3. Hasil Skor Turnament Siklus 1, RPP 2

\begin{tabular}{|c|c|c|c|c|c|}
\hline \multirow[b]{2}{*}{ No } & \multirow[b]{2}{*}{ Hiwar tentang Identitas diri } & \multicolumn{4}{|c|}{ Jawaban siswa } \\
\hline & & $\begin{array}{c}\mathrm{F} \\
\text { Benar }\end{array}$ & (\%) & $\begin{array}{c}F \\
\text { Salah }\end{array}$ & (\%) \\
\hline 1 & Soal A & 2 & 40 & 3 & 60 \\
\hline 2 & Soal B & 3 & 60 & 2 & 40 \\
\hline 3 & Soal C & 3 & 60 & 2 & 40 \\
\hline 4 & Soal D & 3 & 60 & 2 & 40 \\
\hline 5 & Soal E & 5 & 100 & 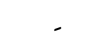 & 0 \\
\hline
\end{tabular}

Dari Tabel 3 didapat hasil bahwa terdapat sedikit peningkatan kemampuan siswa dalam menjawab soal. Kebenaran siswa untuk menjawab soal-soal dengan tingkat kemampuan mudah sangat baik. Hal ini dapat dilihat dari persentase siswa di kelompok yang menjawab pertanyaan dengan benar. Sementara untuk soal-soal dengan kategori sangat sulit juga sudah menunjukkan peningkatan karena terdapat dua siswa yang mampu menjawab benar. Kebenaran jawaban menunjukkan peningkatan seiring dengan semakin dikenalnya model-model pertanyaan yang diberikan. Siswa mulai memahami bagaimana bentuk soal yang akan diberikan guru dari kegiatan diskusi dikelompoknya. Setelah proses pembelajaran dengan menggunakan model belajar kooperatif TGT siklus 1 selesai, maka dilaksanakan ulangan harian untuk mengukur ketuntasan hasil belajar siswa pada siklus 1. Soal ulangan harian terdiri atas 20 soal objektif (Terlampir). Hasil ketuntasan belajar siswa pada siklus 1 disajikan pada Tabel 4 berikut.

Tabel 4. Rekap Hasil Ulangan Harian Siswa Pada Siklus 1

\begin{tabular}{ccccc}
\hline \multirow{2}{*}{ No } & \multirow{2}{*}{ Kompetensi dasar yang diuji 3.2 } & \multicolumn{2}{c}{ Jumlah siswa } & $\begin{array}{c}\text { Keterangan } \\
(\mathbf{k k m}=75)\end{array}$ \\
\cline { 3 - 5 } & & Tuntas & Tidak tuntas & $\%$ tuntas \\
\hline 1 & Hasil tes siklus 1(UH 1) & 22 & 10 & 68,75 \\
\hline
\end{tabular}

\section{Hasil Ketuntasan UH Siklus 1}

Dari data hasil ulangan harian didapatkan hasil ketuntasan belajar pada siklus 1 sebesar $68,75 \%$. Hasil ini belum memenuhi target yang diinginkan yakni sebesar $75 \%$ tuntas. Hasil- hasil skor ulangan harian siklus 1 yang didapatkan oleh siswa selanjutnya di konsultasikan pada kategori tingkat pengetahuan sesuai kriteria yang telah ditetapkan. Hasil analisis kategori pengetahuan konsep siswa pada siklus satu disajikan pada Tabel 5 berikut. 
Tabel 5. Hasil Kategori Pengetahuan Siswa Pada Siklus 1

\begin{tabular}{ccccc}
\hline \multirow{2}{*}{ UH 1 } & \multicolumn{4}{c}{ Kategori } \\
\cline { 2 - 5 } & Amat baik & Baik & Cukup & Kurang baik \\
\hline Jumlah & - & 3 & 25 & 4 \\
\hline Persentase (\%) & 0 & 0,93 & 78,12 & 12,50 \\
\hline
\end{tabular}

Hasil Siklus 2

Setelah didapatkan hasil siklus 1 yang ketuntasan hasil belajarnya belum maksimal maka dilanjutkan ke siklus 2. Untuk menguji tingkat ketuntasan dari kompetensi dasar Menunjukkan struktur teks yang berkaitan dengan والنكرة والمعرفتبأل melakukan dialog yang berkaitan dengan لبيانات الشخصية secara berpasangan didepan kelas. Melakukan kegiatan membaca dan menterjemah teks yang berkaitan dengan لبيانات الثخصية secara nyaring, kembali digunakan model belajar yang sama yaitu TGT, tiap siswa tetap diberi pertanyaan dari tingkat mudah ke tingkat sulit dengan beberapa modifikasi. Hasil skor turnament siklus 2 disajikan pada Tabel 6 berikut.

Tabel 6. Hasil Skor Turnament Siklus 2, RPP 3

\begin{tabular}{|c|c|c|c|c|c|}
\hline \multirow[b]{2}{*}{ No } & \multirow[b]{2}{*}{ Materi Qiraah tentang Identitas diri } & \multicolumn{4}{|c|}{ Jawaban siswa } \\
\hline & & $\begin{array}{c}F \\
\text { Benar }\end{array}$ & (\%) & $\begin{array}{c}\mathrm{F} \\
\text { Salah }\end{array}$ & (\%) \\
\hline 1 & Soal A & 3 & 60 & 2 & 40 \\
\hline 2 & Soal B & 4 & 80 & 1 & 20 \\
\hline 3 & Soal C & 4 & 80 & 1 & 20 \\
\hline 4 & Soal D & 4 & 80 & 1 & 20 \\
\hline 5 & Soal E & 5 & 100 & - & 0 \\
\hline
\end{tabular}

Dari Tabel 6 diatas terlihat bahwa untuk soal tipe $\mathrm{A}$ atau sangat sulit lebih dari $70 \%$ peserta didik sudah dapat menjawab dengan benar, Untuk soal B, C,D persentase ketuntasan menjawab mencapai $80 \%$. sementara untuk tipe soal E, soal mudah dijawab dengan benar oleh setiap perwakilan kelompok. Hasil yang lebih baik ini secara umum menurut peneliti karena siswa sudah terbiasa dengan model permainan TGT. siswa juga telah dapat memprediksi soal-soal yang akan ditanyaakan sebagai hasil dari diskusi di kelompoknya. Selanjutnya Hasil skor turnament 2 siklus 2 (Pertemuan 4) disajikan pada Tabel 7 berikut.

Tabel 7. Hasil Skor Turnament Siklus 2

\begin{tabular}{llccccc}
\hline \multirow{2}{*}{ No } & Materi Tarkib tentang Isim Nakirah & \multicolumn{4}{c}{ Jawaban siswa } \\
\cline { 3 - 6 } & & dan Isim Ma'rifah & Fenar & $(\%)$ & $\begin{array}{c}\text { F } \\
\text { Salah }\end{array}$ & (\%) \\
\hline 1 & Soal A & 5 & 100 & - & 0 \\
2 & Soal B & 4 & 80 & 1 & 20 \\
3 & Soal C & 4 & 80 & 1 & 20 \\
4 & Soal D & 5 & 100 & - & 0 \\
5 & Soal E & 5 & 100 & - & 0 \\
\hline
\end{tabular}

Dari Tabel 7 diatas terlihat bahwa untuk soal tipe $A$ atau sangat sulit telah dapat dijawab benar oleh semua peserta didik di perwakilan kelompok. Untuk soal tipe B dan C lebih dari $80 \%$ peserta didik sudah dapat menjawab dengan benar, Untuk soal D dan E juga telah dapat dijawab 100\% benar oleh setiap perwakilan peserta didik. Pengamatan untuk indikator motivasi belajar pada siklus 2 juga dilakukan oleh observer selain setiap siswa juga mengisi angket. Indikator yang diamati oleh observer untuk motivasi belajar sama dengan siklus 1 yakni adanya motivasi dan hasrat serta keinginan untuk berhasil, adanya dorongan dan kebutuhan untuk belajar, adanya harapan dan cita-cita masa depan, adanya penghargaan dalam belajar dan adanya kegiatan yang menraik saat pembelajaran. Tabel 8 berikut menyajikan hasil survey angket motivasi siswa siklus 2.

Tabel 8. Hasil Pengamatan Motivasi Siklus 2

\begin{tabular}{ccccc}
\hline \multirow{2}{*}{ UH 1 } & \multicolumn{4}{c}{ Kategori Siswa } \\
\cline { 2 - 5 } & A (Sangat baik) & B (baik) & C (cukup) & D (Kurang) \\
\hline Jumlah Siswa & 11 & 19 & 2 & - \\
\hline Persentase (\%) & 34,37 & 59,37 & 6,25 & \\
\hline
\end{tabular}

Pada Tabel 8 terlihat bahwa untuk motivasi belajar siswa pada siklus 2 kategori motivsi sangat baik sebesar 34,37\% atau sebanyak 11 orang, untuk kategori baik sebesar 59,37\% atau sebanyak 19 orang dan kategori cukup sebesar 6,25\% atau sebanyak 2 orang dan tidak terdapat siswa dengan motivsi belajar kategori kurang. Hasil ini menunjukkan peningkatan yang signifikan dari siklus 1 . Setelah proses pembelajaran dengan menggunakan model belajar kooperatif TGT siklus 2 selesai, maka dilaksanakan ulangan harian untuk mengukur ketuntasan hasil belajar siswa pada siklus 2 . Soal ulangan harian terdiri atas 20 soal objektif (Terlampir). Hasil ketuntasan belajar siswa pada siklus 2 disajikan pada Tabel 9 berikut. 
96 Instructional Development Journal (IDJ), Vol. 2, No. 2, Desember 2019, Hal. 91-97

Tabel 9. Rekap Hasil Ulangan Harian Siswa Pada Siklus 2

\begin{tabular}{ccccc}
\hline \multirow{2}{*}{ No } & Kompetensi dasar yang diuji & \multicolumn{2}{c}{ Jumlah siswa } & $\begin{array}{c}\text { Keterangan } \\
(\mathbf{k k m =} \mathbf{7 5})\end{array}$ \\
\cline { 3 - 5 } & & Tuntas & Tidak tuntas & $\%$ tuntas \\
\hline 1 & Hasil tes siklus 2 (UH 2) & 28 & 4 & 87.5 \\
\hline
\end{tabular}

\section{PEMBAHASAN}

Penggunaan model belajar TGT yang dimulai dari siklus satu menunjukkan kebenaran siswa dalam menjawab soal hanya sebanyak 22 orang atau $68,75 \%$ yang tuntas meningkat menjadi 28 orang atau sebesar $87,5 \%$. Hal ini dapat dikarenakan siswa masih asing dengan cara menjawab soal dan belum focus. Menurut Sanjaya (2008), proses belajar adalah proses yang inspiratif, yang memungkinkan siswa untuk mencoba melakukan sesuatu. Maka ketika siswa telah mengetahui tipe soal, maka berarti siswa sudah memiliki sedikit pengalaman. Adanya peningkatan prestasi belajar dengan menggunakan model belajar kooperatif tipe TGT karena siswa telah belajar memahami materi ajar dengan cara berpikir, berdiskusi dan menjawab soal. Pelaksanaan metode ini dikategorikan baik dan dapat dijadikan salah satu pembelajaran yang dapat diterapkan pada prosses pembelajaran selanjutnya. Menurut Saco (2006) model TGT membuat siswa terlibat aktif dan lebih bersemangat karena ada persaingan antar kelompok. Permainan yang dikemas hdalam bentuk tournament ini dapat berperan sebagai alternative atau sebagai review materi pelajaran. Kemampuan guru dalam membangkitkan aktivitas siswa merupakan suatu yang diperlukan selama penelitian berlangsung. Menurut catatan observer, hanya beberapa siswa yang melakukan kegiatan TGT pada awal pertemuan siklus I, siswa yang lainnya hanya bermain-main, menyontek, ketika ditanya oleh guru siswa menjawab tidak memahami dan takut bertanya, malu ditertawakan teman, di saat inilah peranan guru sangat dibutuhkan sebagai fasilitator. Hal ini sesuai dengan pendapat Rogers dalam Dimyati dan Mudjiono (2009), dalam pembelajaran disarankan, agar siswa memperoleh kepercayaan diri untuk mengalami dan menemukan secara bertanggung jawab, hal ini terjadi bila guru bertindak sebagai fasilitator.

Sementara itu dari motivasi belajar pada siklus 1 juga terlihat peningkatan pada siklus 2 dimana terlihat kategori sangat baik meningkat dari 28,12 menjadi 34,37, kemudian kategori baik dari 56,25 meningkat menjadi 59,37 dan terjadi penurunan pada kategori cukup dan kurang. Salah satu cara membangkitkan motivasi belajar ialah dengan menciptakan suasana belajar yang menyenangkan dan menarik. Secara keseluruhan motivasi instrinsik yang dimiliki oleh peserta didik dan didukung oleh motivasi ekstrinsik dapat memicu motivasi belajar peserta didik menjadi lebih tinggi. Menurut Prayitno (2009), adanya faktor motivasi intrinsik sekaligus faktor ekstrinsik dapat menghasilkan motivasi belajar. Sementar itu menurut A M, Sardiman (2014) motivasi dari dalam diri peserta didik seperti dari indikator adanya hasrat dan keinginan berhasil serta adanya harapan dan cita-cita peserta didik membutuhkan faktor pendukung dari luar yang dapat berasal dari adanya dorongan atau hal menarik dalam proses pembelajaran. Adanya peningkatan hasil dan motivasi belajar dengan menggunakan model belajar TGT diharapkan dapat meningkatkan pengetahuan siswa terhadap permasalahan yang akan ditemui didunia nyata (kontekstual). Pelaksanaan metode ini dikategorikan baik dan dapat dijadikan salah satu pembelajaran yang dapat diterapkan pada prosses pembelajaran selanjutnya. Menurut Sanjaya (2008), proses belajar adalah proses yang inspiratif, yang memungkinkan siswa untuk mencoba melakukan sesuatu. Dalam TGT siswa juga dituntut agar dapat belajar mandiri dan berkelompok dengan mencari informasi atau jawaban dari pertanyaan yang timbul sendiri kemudian menyampaikan jawaban/temuannya terhadap pertanyaan tersebut. Jika ini terlaksana maka akan timbul kepercayaan diri dari tiap siswa terhadap kemampuan dirinya sendiri. Hal ini sesuai dengan pendapat Rogers dalam Dimyati dan Mudjiono (2009), dalam pembelajaran disarankan, agar siswa memperoleh kepercayaan diri untuk mengalami dan menemukan secara bertanggung jawab, hal ini terjadi bila guru bertindak sebagai fasilitator.

\section{SIMPULAN DAN SARAN}

\section{Simpulan}

Berdasarkan hasil penelitian yang penulis laksanakan di MAN-1 Pekanbaru di kelas Xsc Agama 1 diperoleh kesimpulan bahwa: 1) hasil belajar siswa dalam mata pelajaran Bahasa arab dengan menggunakan model pembelajaran kooperatif tipe Team Games Tournament (TGT) menunjukkan peningkatan dari siklus 1 ke siklus 2; dan 2) model pembelajaran kooperatif tipe Teams Games Tournament dapat meningkatkan motivasi belajar siswa.

\section{Saran}

Berdasarkan hasil penelitian yang telah dipaparkan sebelumnya, peneliti mengemukakan beberapa saran terkait hasil penelitian yang diperoleh antara lain: 1) model belajar kooperatif tipe TGT dapat dijadikan alternatif model pembelajaran untuk perbaikan hasil belajar bagi pelajaran pelajaran lain; dan 2) model belajar kooperatif tipe TGT dapat dikolaborasikan dengan metode lain agar lebih dapat memaksimalkan kreatifitas dan aktifitas anak. 


\section{DAFTAR RUJUKAN}

A.M, Sardiman., 2014, Interaksi dan Motivasi Belajar Mengajar, Rajawali, Jakarta.

Arikunto, Suharsimi; Suhardjono; Supardi. 2003. Penelitian Tindakan Kelas. Jakarta : Bumi Aksara.

Asbullah, 2008, Peningkatan soft skill guru yang cerdas dan inovatif. Simposium Biologi FKIP. Pekanbaru.

BNSP. 2006. Petunjuk Teknis Pengembangan Silabus dan Contoh/Model Silabus SMA/MA. Jakarta : Departemen Pendidikan Nasional.

Depdiknas. 2004. Rambu-rambu Penetapan Standar Ketuntasan Belajar Minimum dan Analisis Hasil Pencapaian Standar Ketuntasan Belajar. Jakarta

Dimyati dan Mujiono. 2009. Belajar dan Pembelajaran. Jakarta. Rineka Cipta

Hamzah B. Uno dan Satria Koni., 2016, Assessment Pembelajaran, PT Bumi Aksara, Jakarta.

Ibrahim, Muslimin. 2010. Asesmen Berkelanjutan Konsep Dasar, Tahapan Pengembangan dan Contoh. Surabaya : Unesa University Press.

Oemar Hamalik. 2014. Kurikulum dan Pembelajaran. Penerbit Bumi Aksara, Jakarta.

Robert E. Slavin. (2010) Cooperative Learning: Teori, Riset dan Praktik. Bandung: Nusa Media

Satriawan. 2018. http: www. Republika.co. id. [Diakses 10 maret 2019].

Silberman Mell. 1996. Active learning. Yappendis. Yogyakarta

Sumiati dan Asra. 2008. Metode Pembelajaran. CV. Wacana Prima. Bandung

Syahza Almasdi, 2009. Penelitian Tindakan Kelas. Makalah Diklat nasional. Pekanbaru.

Tirto. 2017. Potret Anak Indonesia, Lemah nalar Karena Kurang Membaca. http: // tirto. id/potret-anak-indonesia. [Diakses 10 Maret 2018].

Tim $\begin{gathered}\text { Pekerti-AA PPSP LPP.2007. Panduan Evaluasi Pembelajaran. } \\ \text { http://lpp.uns.ac.id/download/PANDUAN\%20EVALUASI\%20PEMBELAJARAN.pdf, diakses } 28 \text { Mei } 2018\end{gathered}$

Tim Pustaka Yustisiya. 2007. Panduan Penyusunan KTSP Lengkap. Yogyakarta : Pustaka Yustisia

Trianto. (2010). Mendesain Model Pembelajaran Inovatif-Progresif: Konsep landasan dan Implementasinya Pada Kurikulum Tingkat satuan Pendidikan. Jakarta: Kencana

https://gugumgumilarblog.wordpress.com/2015/11/03/makalah-tentang-model-model-pembelajaran-bahasa-arab/ 